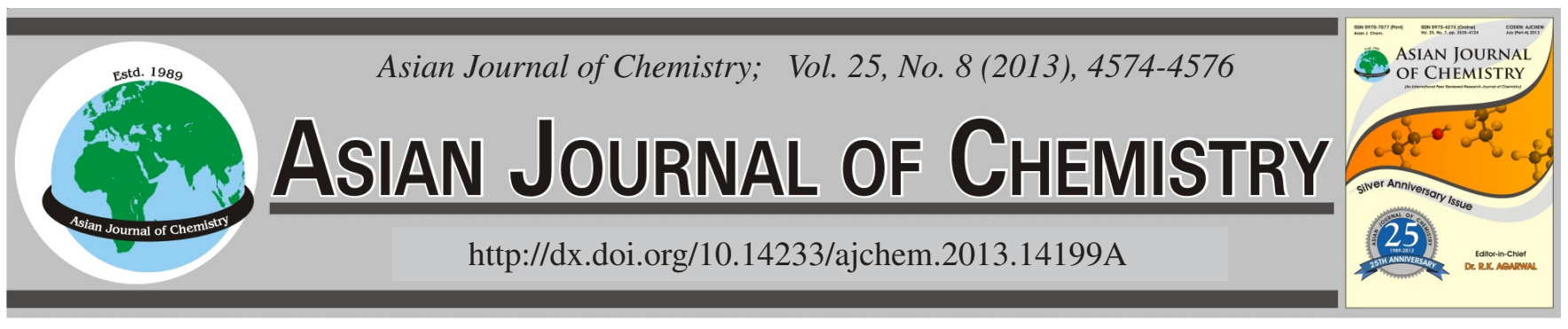

\title{
A Comparative Evaluation of Wound Healing Activity of Various Parts of Clerodendrum infortunatum Linn.
}

PraVEen Kumar ${ }^{*}$ and Laxmi Tripathi

Department of Pharmaceutical Chemistry, S.D. College of Pharmacy and Vocational Studies, Muzaffarnagar-251 001, India

*Corresponding author: E-mail: praveensha77@yahoo.co.in

(Received: 18 June 2012;

Accepted: 18 February 2013)

AJC-13015

\begin{abstract}
In light of the traditional claims and experimental evidences to use Clerodendrum infortunatum Linn. in the treatment of wounds, an investigation was carried out to compare the wound healing activity of methanolic extract of leaves, roots and whole plant of $C$. infortunatum L. The wound healing activity was evaluated using excision, incision and dead space wound models and acute toxicity study was also performed. The study demonstrated a significant increase in the wound healing activity of the methanolic extract of leaves, roots and whole plant of $C$. infortunatum compared with those who received the placebo control treatments. Wound contraction, increased tensile strength and increased hydroxyproline content support the above findings. Among the three extracts the methanolic extract of leaves showed most potent wound healing activity, followed by extract of whole plant and roots.

Key Words: Clerodendrum infortunatum Linn., Wound healing.
\end{abstract}

\section{INTRODUCTION}

Clerodendrum infortunatum Linn. is a perennial shrub belonging to the family Lamiaceae. It is widely distributed in Asia, Australia, Africa and America. A high degree of morphological and cytological variation has been found amongst the species, suggesting the paraphyletic or polyphyletic origin of the genus ${ }^{1}$.

It has been reported for its hepatoprotective ${ }^{2}$, anticonvulsant $^{3}$, antiinflammatory ${ }^{4}$ and antioxidant ${ }^{5}$ activities. Traditionally, the leaves and roots of the plant are employed externally for tumors and certain skin diseases and internally as tonics ${ }^{6}$. In Indian homeopathy, it is used as a remedy for diarrhoea, post natal care and also to dress wounds. The juice of leaves is also believed to possess anthelmintic activity?

The petroleum ether and ethanol extracts of leaves of $C$. infortunatum L. exhibit wound healing activity ${ }^{5}$. The chloroform and ethanol extracts of roots showed significant wound healing activity similar to the standard drug nitrofurazone. The presence of bioactive constituents, including flavonoids, is thought to promote the wound healing process in roots due to their antioxidant and antimicrobial activities ${ }^{8}$.

The present study aims to compare the wound healing activity of methanolic extract of leaves, roots and whole plant of $C$. infortunatum. The leaves, roots and whole plant of $C$. infortunatum were extracted with methanol and subjected to chemical characterization. The dried extract was evaluated for its acute toxicity and wound healing activity in excision, incision and dead space wound models.

\section{EXPERIMENTAL}

The leaves, roots and whole plant of $C$. infortunatum were collected from district Bareilly, India in the month of April and was authenticated In the Department of Pharmacognosy, S.D. College of Pharmacy and Vocational Studies, Muzaffarnagar, India. A voucher specimen (No. PK-123) has been deposited.

Extraction: The dried and powdered leaves, roots and whole plant of $C$. infortunatum were soaked in methanol overnight and extracted in a Soxhlet's apparatus for $24 \mathrm{~h}$ (methanolic extract of leaves of $C$. infortunatum: MLCI, 6.4 $\%$ w/w; methanolic extract of roots of $C$. infortunatum: MRCI, $4.5 \% \mathrm{w} / \mathrm{w}$, methanolic extract of whole plant of $C$. infortunatum: MWCI, $8.2 \% \mathrm{w} / \mathrm{w})$. The crude extract was subjected to chemical characterization and evaluation of wound healing activity and acute toxicity.

Chemical characterization: The dried crude extracts MLCI, MRCI and MWCI were subjected to qualitative chemical tests for the presence of alkaloids, glycosides, tannins, flavanoids, triterpenoids and saponins.

Animals used: The study was approved by Institutional Animal Ethical Committee, S.D. College of Pharmacy and Vocational Studies, Muzaffarnagar. Healthy male sprague dawley rats weighing 200-220 g were used for the study. They 
TABLE-1

WOUND HEALING EFFECT OF VARIOUS PARTS OF $C$. infortunatum IN INCISION WOUND MODEL

\begin{tabular}{lcccc}
\hline Parameter & Placebo control & MLCI & MRCI & MWCI \\
\hline Skin breaking strength & $302.82 \pm 4.3$ & $453.3 \pm 2.73$ & $367.1 \pm 2.13$ & $404.3 \pm 2.5$ \\
\hline $\mathrm{N}=6$, Values are expressed as mean \pm SD & & &
\end{tabular}

were individually housed and maintained on normal food and water ad libitum. The rats were anaesthetized prior to and during infliction of the experimental wounds. The surgical intervention was carried out under sterile conditions using ketamine anaesthetic $(120 \mathrm{mg} / \mathrm{kg})$.

Acute toxicity study: In acute toxicity test the rats were fed with increasing doses (1, 2, 4 and $8 \mathrm{~g} / \mathrm{Kg}$ body weight) of MLCI, MRCI and MWCI for 14 days. The animals were allowed access to food and water and behaviour changes were observed for a period of $72 \mathrm{~h}$ for any sign of acute toxicity.

Wound healing activity: Excision, incision and dead space wound models were used to evaluate the wound-healing activity of $C$. infortunatum.

Excision wound model: Animals were anaesthetized prior to and during creation of the wounds. The rats were inflicted with excision wounds as described by Morton and Malon'. The animals were divided into two groups of 6 each. Group 1 animals were topically treated with the carboxymethyl cellulose $(100 \mathrm{mg} / \mathrm{kg} /$ day $)$ as a placebo control. The animals of group 2 were topically treated with the MLCI, MRCI and MWCI at a dose of $100 \mathrm{mg} / \mathrm{kg} /$ day till complete epithelization. The wound closure rate was assessed by tracing the wound on days 1, 5 and 15 post-wounding using transparency paper and a permanent marker. The wound areas recorded were measured using a graph paper. Number of days required for falling of eschar without any residual raw wound gave the period of epithelization.

Incision wound model: A longitudinal paravertebral incision, six centimeters in length was made through the skin and cutaneous muscle on the back as described by Ehrlich and Hunt et $a l .{ }^{10}$. After the incision, surgical sutures were applied to the parted skin at intervals of one centimetre. The wounds were left undressed. The rats were given MLCI, MRCI and MWCI (dissolved in drinking water) orally at a dose of $100 \mathrm{mg} \mathrm{kg}^{-1}$ day $^{-1}$. The controls were given with normal saline. The sutures were removed on the $8^{\text {th }}$ post wound day and the treatment was continued. The skin-breaking strength was measured on the $10^{\text {th }}$ day by the method described by Lee ${ }^{11}$.

Dead space wound model: Dead space wounds were inflicted by implanting two sterilized cotton pellets $(10 \mathrm{mg})$, one on either side of in the lumbar region on the ventral surface of each rat. On the $10^{\text {th }}$ postwounding day, the granulation tissue formed on the implanted cotton pellet was carefully removed. The wet weight of the granulation tissue was noted. These granulation tissues were dried at $60{ }^{\circ} \mathrm{C}$ for $12 \mathrm{~h}$ and weighed and the weight was recorded. To the dried tissue $5 \mathrm{~mL}$ of $6 \mathrm{~N} \mathrm{HCl}$ was added and kept at $110^{\circ} \mathrm{C}$ for $24 \mathrm{~h}$. The neutralized acid hydrolyzate of the dry tissue was used for the determination of hydroxyproline ${ }^{12}$.

Determination of wound breaking strength: The anesthetized animal was secured to the table and a line was drawn on either side of the wound $3 \mathrm{~mm}$ away from the line. This line was gripped using forceps one at each end opposed to each other. One of the forceps was supported firmly, whereas the other was connected to a freely suspended light weight metal plate. Weight was added slowly and the gradual increase in weight, pulling apart the wound edges. As the wound just opened up, addition of weight was stopped and the weights added was noted as a measure of breaking strength in grams. Three readings were recorded for a given incision wound and the procedure was repeated on the contralateral wound. The mean reading for the group was taken as an individual value of breaking strength. The mean value gives the breaking strength for a given group.

Estimation of hydroxyproline: Hydroxyproline present in the acid hydrolyzate of granulation tissue oxidized by sodium peroxide in the presence of copper sulfate, when complexed with $p$-dimethylamino bezaldehyde, develops a pink colour that was measured at $540 \mathrm{~nm}$ using colorimetry.

Statistical analysis: Results, expressed as mean \pm SD were evaluated using student's $t$-test.

\section{RESULTS AND DISCUSSION}

The qualitative tests used to identify phytochemical constituents of the $C$. infortunatum showed the presence of glycosides, triterpenoids, tannins, saponins and flavonoids in leaves, roots and whole plant of $C$. infortunatum.

In acute toxicity studies of methanolic extract of leaves, roots and whole plant of $C$. infortunatum, the animals did not produce any signs of toxicity and mortality at the highest administered dose.

The significant increase in the wound-healing activity was observed in the animals treated with the methanolic extract of leaves, roots and whole plant of $C$. infortunatum compared with those who received the placebo control treatments. Table1 shows the effects of the methanolic extract $C$. infortunatum administered orally at a dose of $100 \mathrm{mg} \mathrm{kg}^{-1}$ day $^{-1}$ for 10 days on wound healing activity in rats inflicted with incision wound. In the incision wound model, a significant increase in the wound breaking strength was observed when compared with the controls. In the excision wound model, $C$. infortunatum treated animals showed a significant reduction in the wound area and epithelization period (Table-2). In the dead space wound model (Table-3), the methanolic extract-treated animals showed significantly increased levels of hydroxyproline content as compared with the control group of animals. A significant increase was observed in the weight of the granulation tissue in the animals treated with the extract. Among the three extracts the methanolic extract of leaves showed most potent wound healing activity, followed by extract of whole plant and roots.

\section{Conclusion}

The present study has demonstrated that a methanolic extract of $C$. infortunatum has properties that render it capable of promoting accelerated wound healing activity compared 
TABLE-2

WOUND HEALING EFFECT OF VARIOUS PARTS OF C. infortunatum IN EXCISION WOUND MODEL

\begin{tabular}{|c|c|c|c|c|}
\hline Parameter & Placebo control & MLCI & MRCI & MWCI \\
\hline \multicolumn{5}{|l|}{ Wound area $\left(\mathrm{mm}^{2}\right)$} \\
\hline Day 1 & $209.3 \pm 2.91$ & $212.4 \pm 1.8$ & $208.7 \pm 2.1$ & $210.2 \pm 1.0$ \\
\hline Day 5 & $155.0 \pm 1.96$ & $117.5 \pm 2.1$ & $150 \pm 1.54$ & $132 \pm 2.41$ \\
\hline Day 15 & $126.42 \pm 1.32$ & $78 \pm 2.3$ & $118 \pm 1.8$ & $92.3 \pm 1.4$ \\
\hline Period of epithelization (day) & $16 \pm 2.3$ & $9.5 \pm 1.9$ & $13.2 \pm 2.1$ & $11.1 \pm 0.92$ \\
\hline
\end{tabular}

TABLE-3

WOUND HEALING EFFECT OF C. infortunatum IN DEAD SPACE WOUND MODEL

\begin{tabular}{|c|c|c|c|c|}
\hline Parameter & Placebo control & MLCI & MRCI & MWCI \\
\hline Wet weight of granulation tissue (mg/100 g rat) & $75.9 \pm 2.2$ & $99.3 \pm 2.5$ & $80.1 \pm 2.5$ & $87.6 \pm 1.33$ \\
\hline Dry weight of granulation tissue (mg/100 g rat) & $6.70 \pm 0.51$ & $18.14 \pm 2.65$ & $8.05 \pm 2.31$ & $13.5 \pm 2.1$ \\
\hline Hydroxyproline (mg/g tissue) & $26.4 \pm 1.2$ & $70.23 \pm 2.0$ & $44.3 \pm 1.88$ & \\
\hline
\end{tabular}

with placebo controls. Wound contraction, increased tensile strength and increased hydroxyproline content support the above finding. The presence of bioactive constituents including flavonoids, are thought to promote the wound-healing process in roots ${ }^{8}$. Flavanoids and other bioactive constituents are also shown to be present in leaves and whole plant of $C$. infortunatum through chemical characterization test. Any one of the observed phytochemical constituents present in methanolic extract of leaves, roots and whole plant of $C$. infortunatum may be responsible for the wound healing activity of the plant. As it is observed that the methanolic extract of leaves shows most potent wound healing activity, it may be concluded that the bioactive compound reponsible for the activity is present in highest concentration in leaves followed by whole plant and roots. Further studies are required to isolate the active constituents responsible for wound healing activity.

\section{REFERENCES}

1. D.A. Steane, R.W. Scotland, D.J. Mabberley and R.G. Olmstead, Am. J. Bot., 86, 98 (1999).

2. S. Sannigrahi, U.K. Mazumder, D. Pal and S.L. Mishra, Pharmacog. Maz., 5, 394 (2009).

3. S. Das, P.K. Haldar, G. Pramanik, S.P. Panda and S. Bera, Thai J. Pharm. Sci., 34, 129 (2010).

4. S. Das, P.K. Haldar, G. Pramanik and R.B. Suresh, Global J. Pharmacol., 4, 48 (2010).

5. G. Kuluvar, R. Mahmood and H. Manjunatha, Environ. Toxicol. Pharmacol., 30, 11 (2010).

6. J.M. Maisch, Am. J. Pharm., 57 (1885).

7. B.M. Rajurkar, Int. Res. J. Pharm., 2, 130 (2011).

8. G. Kuluvar, R. Mahmood, B. Mohamed, K. Ahamed, P.S. Babu and V. Krishna, Int. J. Biomed. Pharm. Sci., 3, 21 (2009).

9. J.J.P. Morton and M.H. Malone, Arch. Int. Pharmacodyn., 196, 117 (1972).

10. H.P. Ehrlich and T.K. Hunt TK, Ann. Surg., 167, 324 (1968).

11. K.H. Lee, J. Pharm. Sci., 57, 1042 (1968).

12. R.E. Neuman and M.A. Logan, J. Biol. Chem., 184, 299 (1950). 